\title{
Characteristics of a Triassic regional unconformity between the second and third shallow-marine depositional megasequences of the Karst Dinarides (Croatia)
}

\author{
Damir Bucković \\ Department of Geology, Faculty of Science, \\ University of Zagreb, Zagreb
}

\begin{abstract}
Two depositional megasequences of the Karst Dinarides that record two different, emersionseparated, depositional periods are presented; the older lasted from the upper part of the Middle Permian to the Middle Triassic, and the younger one from the Late Triassic to the Late Cretaceous. Both megasequences are typified by shallow-water platform deposits; the earlier megasequence formed under epeiric carbonate/clastic platform conditions and the later one under isolated carbonate platform conditions. Significant geodynamic movements within the southern Tethys realm led to Middle Triassic tectonic uplift, i.e. to the emersion of the huge platform area where a regional unconformity between two platform megasequences was formed. Four types of terrestrial phase horizons are identified, each representing different subaerial conditions that existed during the longlasting emersion. These are: a significant disconformity and related stratigraphic gap between the Upper Scythian and Lower Norian; a tuffaceous horizon between the Upper Anisian and Lower Norian; an Upper Ladinian-Upper Norian brecciated horizon; and an Upper Ladinian-Lower Norian claystone/bauxitic horizon. Due to the widespread diachronous transgression during the Norian, shallow-water platform sedimentation was restored over the entire emergent area, initiating a longlasting isolated carbonate platform regime.
\end{abstract}

Key words: Triassic, unconformity, terrestrial phase horizons, depositional megasequence, Karst Dinarides, Croatia

\section{Introduction}

Within the history of the shallow-marine carbonate deposition in the Karst Dinaridic area, four depositional megasequences can be recognized: 1) carbonate/ clastic megasequence ranging from the Lower Carboniferous to the Lower Permian, 2) carbonate/clastic megasequence ranging from the upper part of the

Address: D. Bucković: Horvatovac 102a, 10000 Zagreb, Croatia, e-mail: buckovic@geol.pmf.hr Received: May 20, 2008; accepted: July 9, 2008 
Middle Permian to the Middle Triassic; 3) carbonate megasequence ranging from the Upper Triassic to the Late Cretaceous; and 4) carbonate/clastic megasequence ranging from the Paleocene to the Middle Eocene. These megasequences are separated by regional unconformity and terrestrial deposits, marking regionally important emersion phases (Velić et al. 2002).

This study focuses on the emersion phase between the second and the third depositional megasequence. Deposition of the second megasequence occurred contemporaneously along the northern Gondwana shelf area, i.e. on an epeiric carbonate platform (Ramovš et al. 1990; Krainer 1993; Jurković and Pamić 2001; Kiessling et al. 2003; Sremac 2005). From the upper part of the Middle Permian to the end of the Permian, the continuous shallow-water platform sedimentation on the epeiric platform area produced a few hundred meters-thick carbonate sequence (Kochansky-Devidé 1965; Sokač et al. 1976). However, during the Early Scythian carbonate production was choked up by intensive inputs of terrestrial material derived by fresh water flows from the Gondwana hinterland. Partly during the Late Scythian and during the entire Anisian/Ladinian, shallow-water carbonate platform sedimentation was restored, but was soon interrupted by a tectonically induced regional emersion, separating the second and the third megasequence of today's Karst Dinarides. The third megasequence deposition began during the Norian and consists of pure carbonate deposits that are the signature of an isolated carbonate platform depositional regime, only sporadically punctuated by "short" periods of subaerial exposure and pelagic drowning episodes (e.g. Vlahović et al. 2005; Husinec and Jelaska 2006). Between two depositional megasequences, i.e. during the regional emersion phase, various types of terrestrial phase horizons originated. They are examined on four widely separated sections of the Karst Dinarides due to their stratigraphic range, facies characteristics and environmental conditions.

\section{Facies characteristics of the sections and terrestrial phase horizons}

Within the Triassic sedimentary signature of the Karst Dinarides, four representative sections have been chosen (Figs 1 and 2), each with a different type of the terrestrial phase horizon, formed in particular terrestrial environments and under identifiable sedimentary conditions.

\section{The Zelovo Section (Mt. Svilaja)}

Mt. Svilaja is the third highest mountain in Dalmatia and the sixth highest in Croatia. The foothills of Mt. Svilaja (Zelovo area) are a well-known locality comprising a thick succession of Triassic strata (Figs 1a and 2a). The Lower Triassic deposits are thrust over the underlying Eocene carbonates and can be divided into two lithostratigraphic units. The Lower Scythian unit is composed of thinbedded, reddish and violet micaceous siliciclastic intervals, composed of 


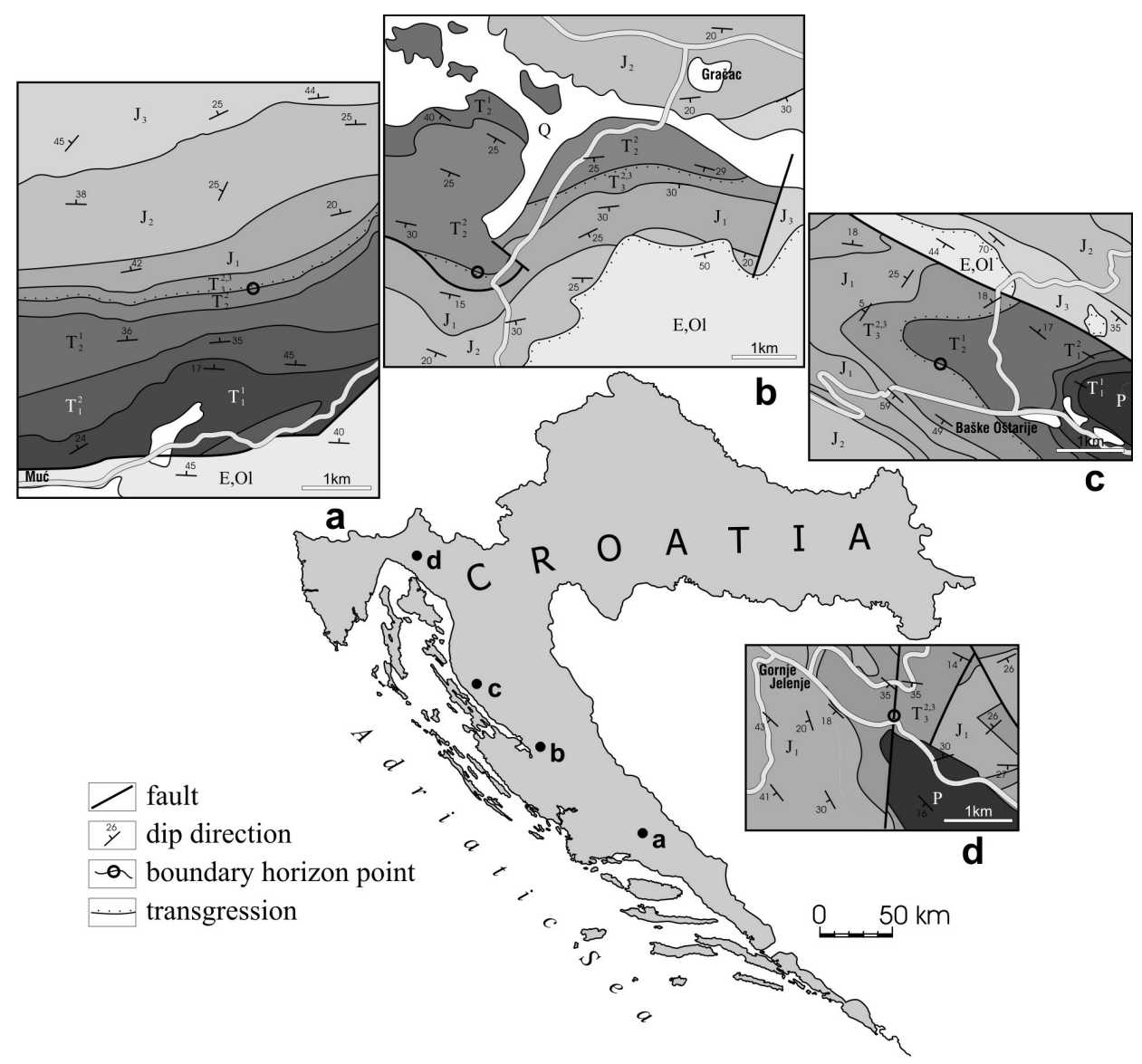

Fig. 1

Geographical positions of the studied boundary horizons (studied boundary horizons are exposed within the circle): a - Zelovo; b - Vrace; c - Baške Oštarije; d - Rogozno. Geologic sketches a-d according to Basic Geological Map 1:100000, sheets: Sinj (Papeš et al. 1982) (a); Obrovac (Ivanović et al. 1973) (b); Gospić (Sokač et al. 1974) (c); Delnice (Savić and Dozet 1984) (d) (all modified). Legend: $\mathrm{P}$ - Permian; $\mathrm{T}_{1}^{1}$ - lower Lower Triassic; $\mathrm{T}_{2}^{1}$ - upper Lower Triassic; $\mathrm{T}_{1}^{2}$ - lower Middle Triassic; $\mathrm{T}_{2}^{2}-$ upper Middle Triassic; $\mathrm{T}_{23}^{3}$ - Upper Triassic; $\mathrm{J}_{1}$ - Lower Jurassic; $\mathrm{J}_{2}$ - Middle Jurassic; $\mathrm{J}_{3}$ - Upper Jurassic; E, Ol - Eocene, Oligocene; Q - Quaternary

siltstone/sandstone, alternating with thicker-bedded, siliciclastic-carbonate intervals, composed of oolite/sandstone. These facies types are characterized by an abundant variety of textures, such as sharp lower bedding surfaces, ripple cross-lamination, hummocky cross-lamination, horizontal planar lamination, etc. The increasing occurrence of micritic limestone and marl versus siltstone, together with a lack of sandstone and ooid grainstone, characterize the Upper Scythian unit. Well-preserved gutter casts, numerous escape burrows and crawling trace fossils, undulatory lamination and hummocky cross-stratification 


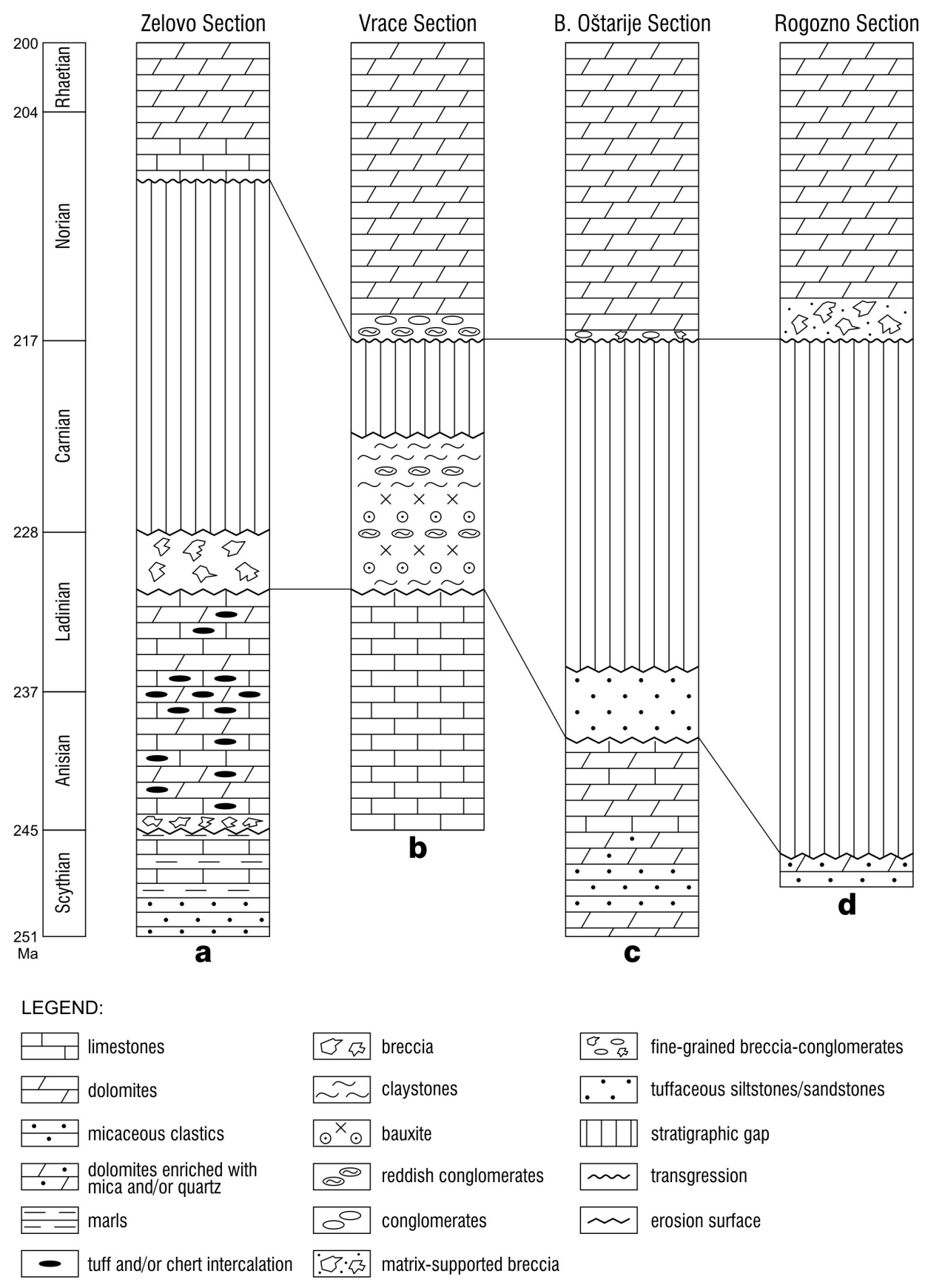

Fig. 2

Chronostratigraphy and correlation of studied sections and terrestrial phase horizons 
are common texture characteristics of these beds. Unlike the Lower Scythian one this unit is very rich in various mollusks, such as small gastropods, bivalves and ammonites (Dinarites sp., Tirolites sp.). The thickness of the Lower Triassic succession in the Zelovo area amounts to ca. $330 \mathrm{~m}$ (Jelaska et al. 2003).

The boundary between the Upper Scythian unit and the Anisian is marked by the so-called "Otarnik" unit. It is represented by a 13 m-thick interval of carbonate breccia and mud-pebble conglomerate that passes laterally and vertically into the Anisian carbonates. Within their thickness of $55 \mathrm{~m}$ the Anisian carbonates contain more or less clear traces of volcanism; limestone and dolomite beds are punctuated by numerous cm-to-dm thick tuff intercalations, a few mm-thick chert intercalations, and frequent pervasive silicification.

The limestone beds include bioclastic wackestone with sporadic abundance of calcitized and/or recrystallised radiolarians, sponge spicules, ostracodes and crinoid ossicles. Particles of undeterminable corals, mollusks, and brachiopods are rarely present. Sporadic findings of the Late Anisian - Ladinian foraminifera "Planiinvoluta" mesotriasica Baud, Zaninetti and Bronnimann and Trochammina almtalensis Koehn-Zaninetti coincide with a $20 \mathrm{~m}$-thick interval of silicified dolomite and limestone that alternate with green, crystalline and vitric tuffs known as "pietra verde" (Jelaska et al. 2000).

The "pietra verde" interval is covered by an 80 m-thick interval of Ladinian bioclastic wackestone/floatstone alternating with dolomite. The wackestone/ floatstone, only sporadically intercalated with chert, frequently contain recrystallised fragments of Diplopora annulata Schafhäutl (Fig. 3a), oncoids, crinoidal detritus and stromatolitic intraclasts. Silicification of limestone beds is quite rare. These carbonates represent the termination of the Ladinian at the foothills of Mt. Svilaja. Their topmost surface is intensely brecciated, representing the terrestrial phase horizon.

The breccia horizon is $4 \mathrm{~m}$ thick. It is composed of angular and subangular limestone and dolomite fragments that vary in size from a few $\mathrm{mm}$ to a few $\mathrm{cm}$ (Fig. 3b). Larger fragments occur only sporadically. Some fragments contain calcite and/or dolomite veins. At places, the breccia contains rounded fragments, thus passing into a conglomerate. The packing of breccia fragments is dense, while their sorting is poor, without grading or bedding. The predominant type of fragments is white, bioclastic wackestone/floatstone containing Diplopora annulata Schafhäutl. Other wackestone/floatstone fragments contain rare undeterminable mollusk remains, rounded intraclasts and rare oncoids. Dolomite fragments consist of subhedral to euhedral dolomite crystals with only sporadically preserved original sedimentary structures, such as stromatolitic lamination. The matrix of the breccia consists of fine-grained limestone and/or dolomite particles, enriched with reddish bauxitic clayey material. Some larger carbonate particles, incorporated in the matrix, are completely recrystallised. In spots, coarser sparry crystals occur. Sporadic larger cavities are partly matrix-filled or in part sparfilled, revealing geopetal fabrics. 


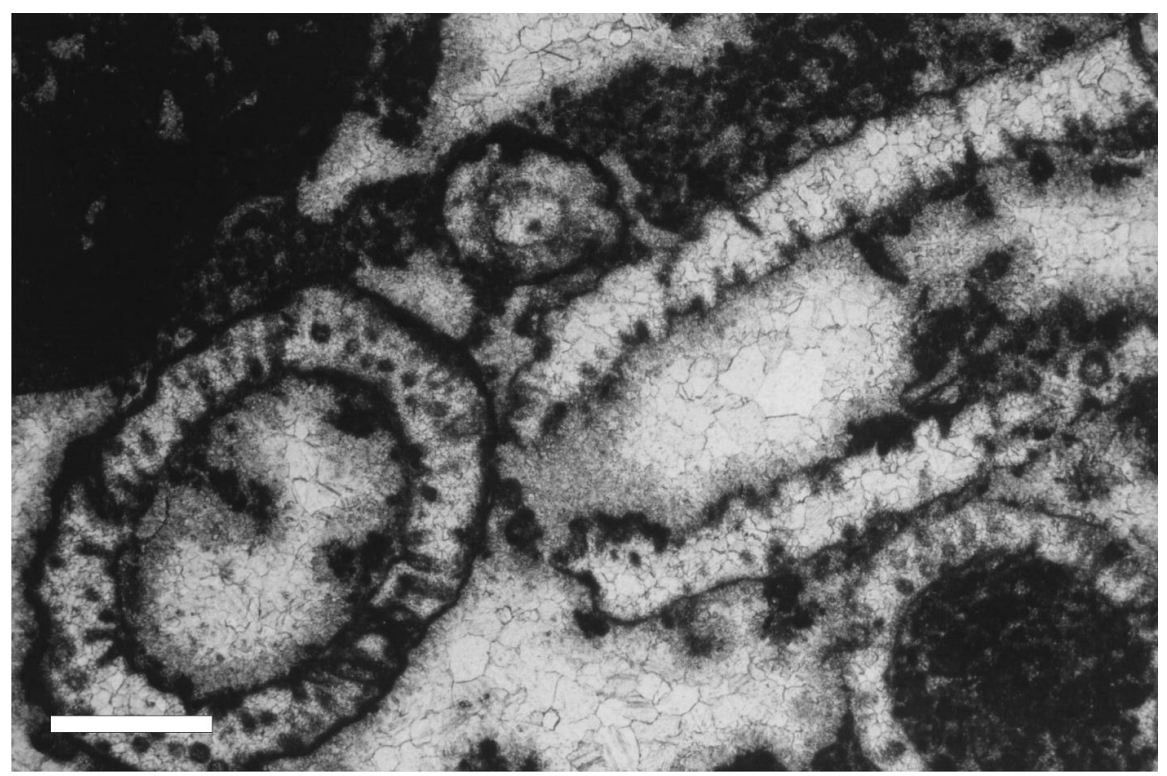

Fig. 3a

Zelovo section. Bioclastic floatstone with Diplopora annulata Schafhäutl. Late Ladinian. Scale bar $1.2 \mathrm{~mm}$

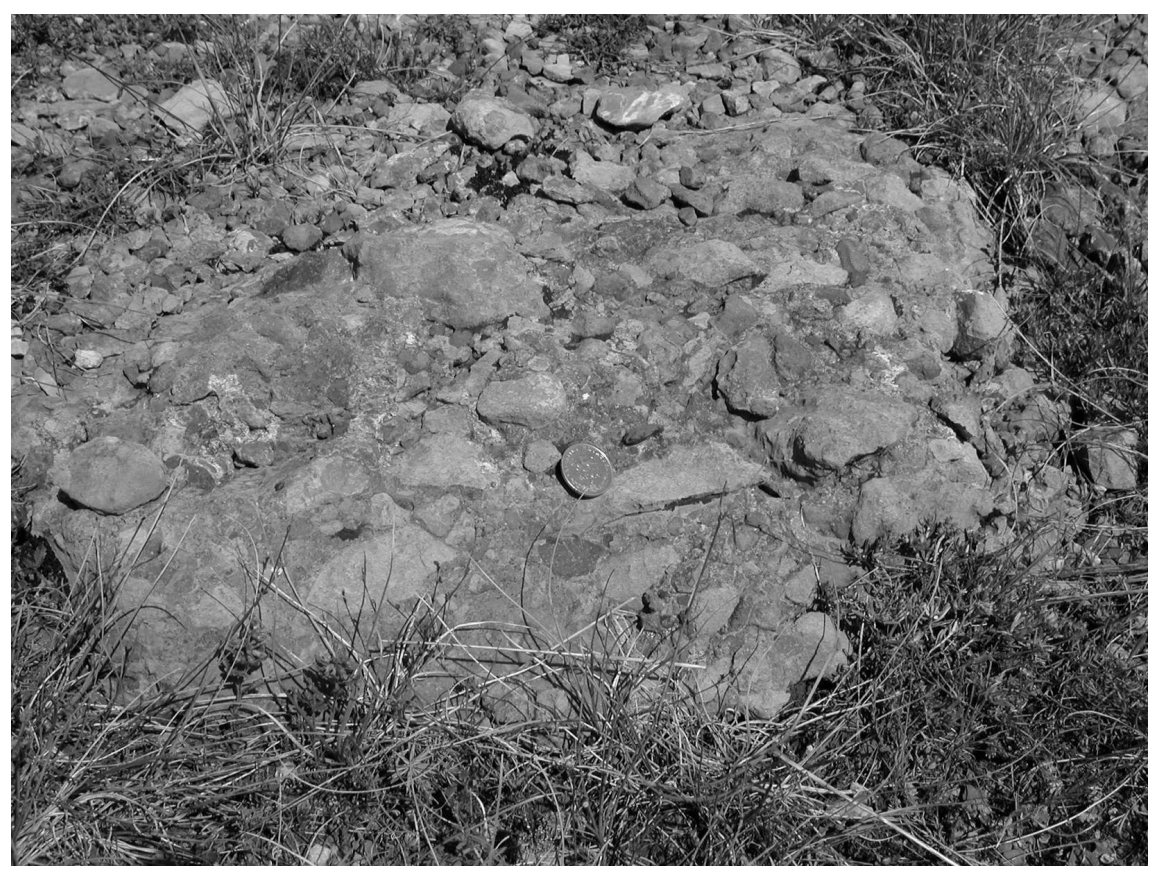

Fig. $3 b$

Zelovo section. The breccia horizon composed of Upper Ladinian limestone and dolomite fragments

Central European Geology 51, 2008 
The breccia horizon is overlain by an $8 \mathrm{~m}$-thick interval of grain-supported, oolitic-foraminiferal packstone, with the Late Norian to Rhaetian foraminifera Triasina hantkeni Majzon and Aulotortus sp. This is, in turn, followed by $60 \mathrm{~m}$-thick succession of late diagenetic dolomite with sporadic planar and corrugated stromatolitic lamination. This dolomites is thin to medium-bedded $(0.1-0.4 \mathrm{~m})$, moderate gray and/or in places yellowish gray in color, due to weathering and limonitization of pyrite grains. Early-diagenetic dolomitic varieties, dolomitic limestone as well as dedolomite, respectively, occur sporadically. The latediagenetic dolomitic beds are monotonous, composed of predominantly subhedral and to a lesser extent euhedral dolomite crystals, ranging in size from $0.1-0.4 \mathrm{~mm}$, so the primary structures are not visible. In places, it even has a sandy appearance. The early-diagenetic dolomitic beds show a heterogeneous microfacies composition, with numerous lithological varieties such as dolosparite, dolointrasparite, dolomicrite, dolopelmicrite and/or stromatolitic dolomite. Desiccation and erosion processes ripped up the stromatolitic laminae, locally forming an intraformational dolomite breccia. Abundant, irregular fenestrae and sporadic undeterminable algal fragments, mollusks and ostracodes also occur. The irregular fenestrae frequently show geopetal characteristics. Triasina hantkeni Majzon and Aulotortus sinuosus Weynschenk can be found sporadically in dolopelmicrite.

\section{The Vrace Section (Mt. Velebit)}

Carbonate deposits are known at Mt. Velebit from the Carboniferous, Permian, Triassic and Jurassic. The Triassic carbonates of the Vrace area (Fig. 2b) are ca. 200 $\mathrm{m}$ thick, partly covered by Quaternary marsh sediments (Fig. 1b). Both the Anisian and Ladinian sections include medium to thick-bedded (0.4-1.5 m) successions of bioclastic wackestone/floatstone, sporadically rich with various dasycladaceans. In Anisian beds are found Macroporella alpina Pia, Diplopora hexaster Pia and Diplopora proba Pia, whereas Ladinian deposits predominantly contain Diplopora annulata Schafhäutl and Teutloporella herculea (Stoppani) (Ivanović 1976). Variable amounts of peloids as well as mollusk and ostracode fragments also occur. Foraminifera are very rare. The matrix is clotted micrite with sporadically abundant irregular fenestrae filled with fibrose and drusy calcite.

The upper part of Ladinian bioclastic wackestone/floatstone is overlain by terrigenous deposits, representing the terrestrial phase horizon (Fig. 4a). It is represented by ferruginous chlorite-kaolinite claystone, bauxite and reddish conglomerate. According to Šinkovec (1970) and Tišljar et al. (1991) the bauxite horizon is $18 \mathrm{~m}$ thick, revealing an oolitic-crystalline granular and/or pelitic to pseudoporphyric texture. The main mineral is diaspore, while hematite, kaolinite, boehmite and chlorite are subordinated. The bauxite horizon is separated in two layers by an approximately 2 m-thick bed of reddish 


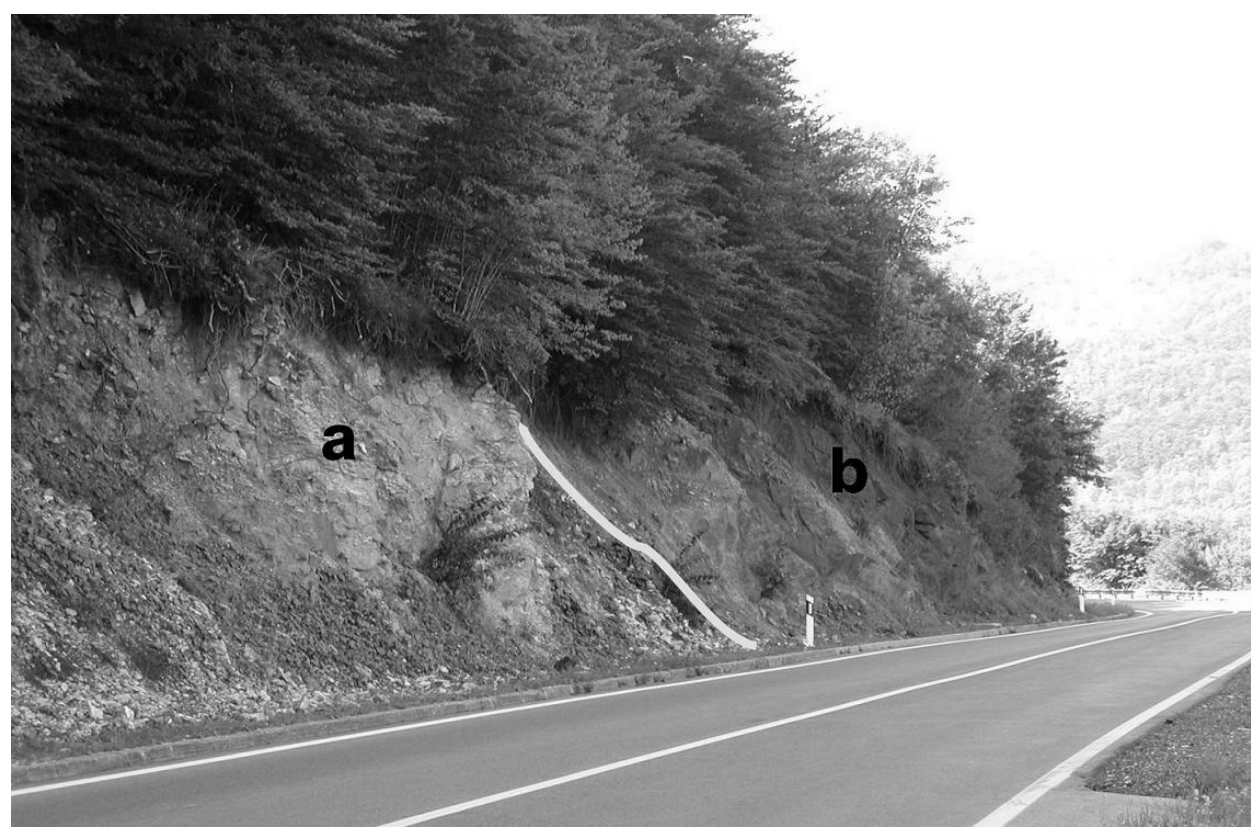

Fig. 4a

Vrace section. Line marks the contact between the Ladinian bioclastic wackestone/floatsone (a) and terrestrial phase horizon (b)

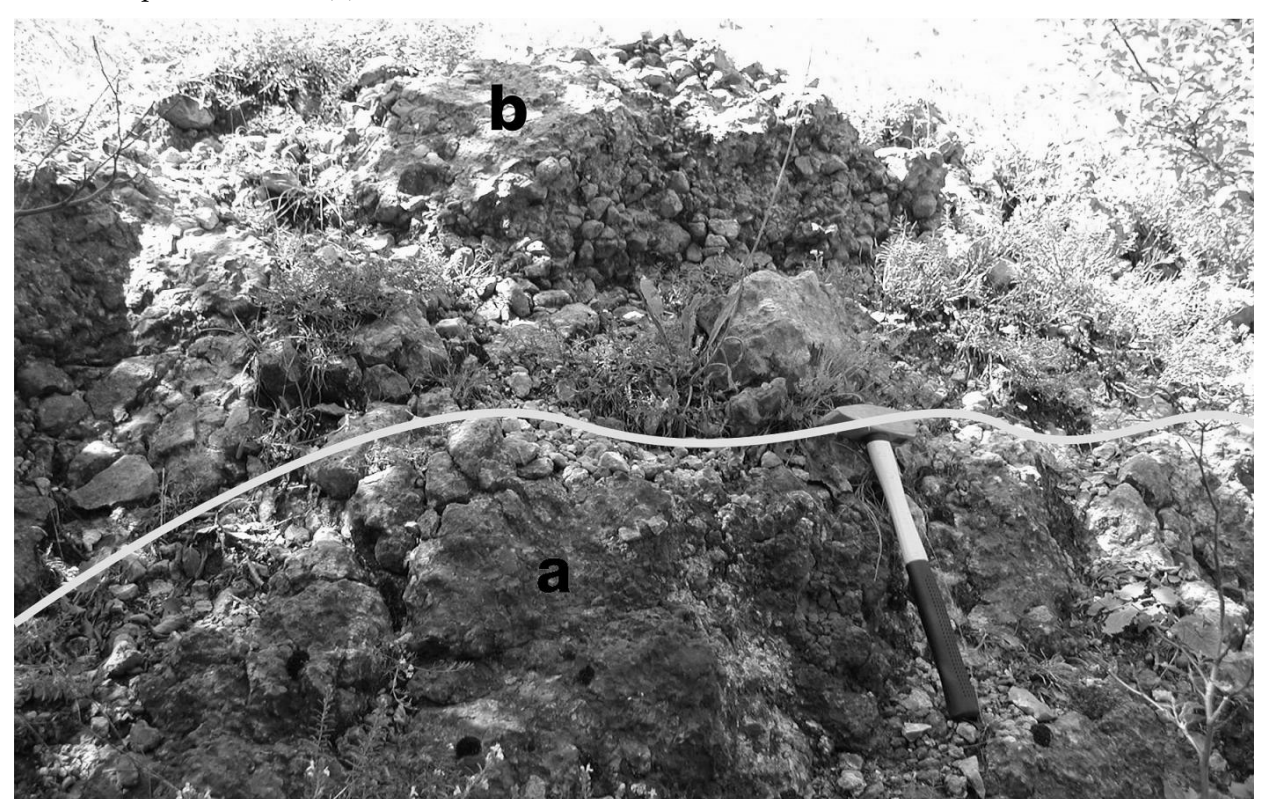

Fig. $4 \mathrm{~b}$

Vrace section. Line separates reddish conglomerate (a) overlain by carbonate conglomerate (b) 
conglomerate. This bed contains resedimented claystone pebbles and sporadic pebbles of Ladinian bioclastic wackestone/packstone, $0.05-0.2 \mathrm{~m}$ in diameter. Overlying the bauxite horizon are $22 \mathrm{~m}$ of thick purple-colored ferruginous claystone and reddish conglomerate in irregular alteration. These deposits are overlain by carbonate conglomerate of approximately $200 \mathrm{~m}$ of lateral extent. This very abruptly changes in thickness from a few $\mathrm{dm}$ to $1 \mathrm{~m}$, occasionally overlying ferruginous claystone and/or, in places, reddish conglomerate (Fig. 4b). The packing of conglomerate limestone pebbles is dense and sorting is good, without grading. Within this conglomerate interval two parts can be distinguished. In the lower part, subrounded to rounded pebbles of Ladinian bioclastic wackestone/ floatstone, $0.01-0.05 \mathrm{~m}$ in diameter, contain a relatively high percentage of ferruginous matrix, while in its upper parts, in contrast, the ferruginous content of the matrix either decreases or disappears (Tišljar et al. 1991). This carbonate conglomerate is followed by a $140 \mathrm{~m}$-thick succession of Norian-Rhaetian dolomite. Its structural characteristics fully correspond to those of the Zelovo section.

\section{The Baške Oštarije Section (Mt. Velebit)}

The succession in the wider area of Baške Oštarije provides evidence of shallow-marine deposition from the Middle Permian (Kungurian) to the Oligocene (Fig. 1c). For the purposes of this study, however, attention was focused on Triassic strata (Fig. 2c). The Lower Triassic deposits conformably overlay the Permian (Fio et al. 2006, 2007). In contrast to the Zelovo section, the Lower Triassic comprises three lithostratigraphic units; the lower unit is composed of dolomite, the middle unit contains reddish and violet micaceous clastics and the upper unit includes dolomite with sporadic traces of micaceous clastics (Sokač et al. 1974, 1976). The thickness of the Lower Triassic deposits amounts to ca. $300 \mathrm{~m}$.

The Anisian beds, medium to thick-bedded (0.3-1.1 m), are characterized by lateral and vertical alternation of dolomite and limestone that conformably overlie Lower Triassic dolomite. The Anisian dolomite is mostly medium to light gray with yellowish, rusty brown color at weathered surfaces. Two main types of dolomite can be observed: late-diagenetic, micro- to macrocrystalline, composed of anhedral to euhedral dolomite crystals without any preserved sedimentary texture, and early-diagenetic varieties that include dolomicrite, fenestral dolomicrite and dolomitic stromatolite with very fine undulating laminations. Dolomitic stromatolite is sporadically fragmented, forming few $\mathrm{cm}$-thick intraformational breccia intervals. The strata with the Anisian microfauna are represented by mostly recrystallised peloidal-bioclastic wackestone/packstone, frequently interlayered with dolomitized limestone. Among the pellets, peloids and undeterminable mollusk fragments occurring in the recrystallised groundmass, the microfossil content is very poor. The upper part of the Anisian 
succession includes sporadic findings of the Anisian species Meandrospira dinarica Kochansky-Devidé and Pantić (Fig. 5a) and the Late Anisian species Endothyranella lombardi Zaninetti and Brönnimann (Fig. 5b) and Duostomina sp.

The topmost bed of the ca. $200 \mathrm{~m}$-thick Anisian succession is characterized by a discrete, $0.1 \mathrm{~m}$-thick karstified surface, intersected by numerous dissolutionenlarged fractures, thus forming its brecciated appearance with fragments up to
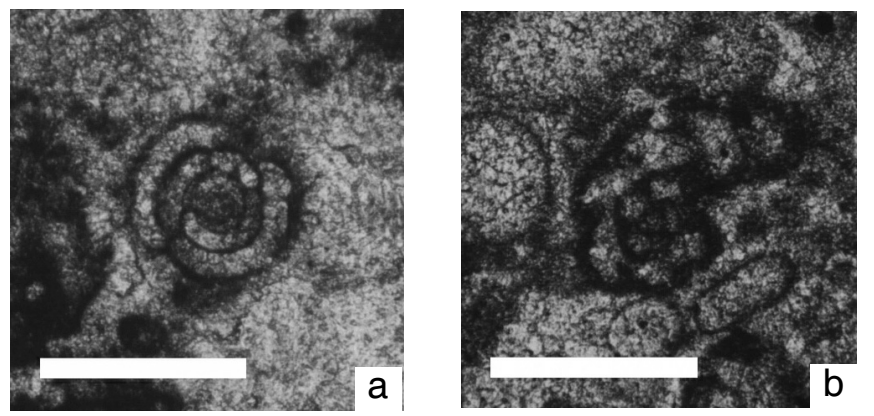

Fig. 5

Baške Oštarije section

Recrystallized peloidalbioclastic wackestone with a) Meandrospira dinarica Kochansky-Devide and Pantic. Late Anisian. Scale bar $0.4 \mathrm{~mm}$, b) with Endothyranella lombardi Zaninetti and Brönnimann. Late Anisian. Scale bar $0.4 \mathrm{~mm}$

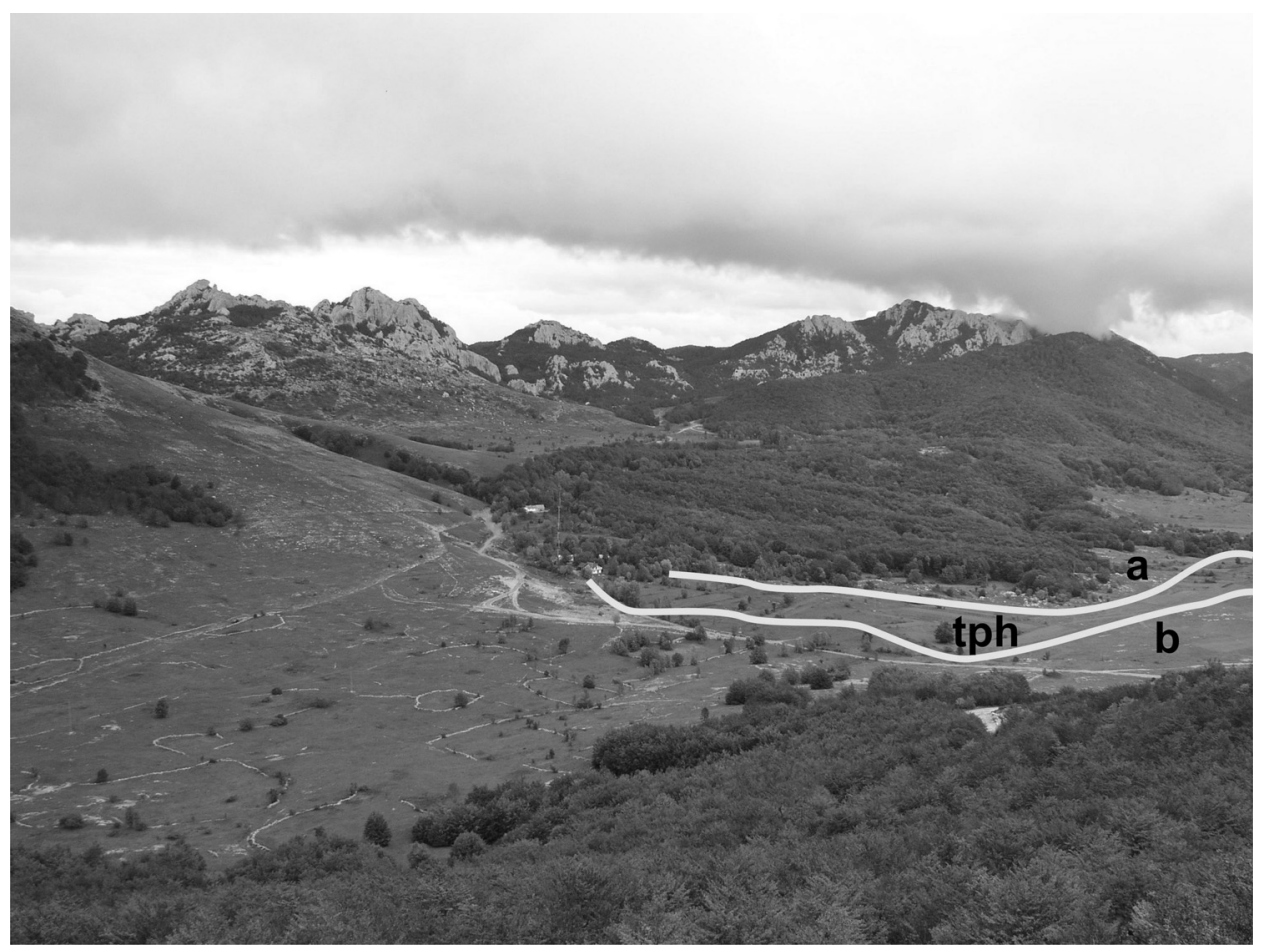

Fig. 5c

Baške Oštarije section. Fine-grained reddish argillaceous siltstone/sandstone of the terrestrial-phase horizon (tph). Lines mark its contact with the Upper Anisian carbonates (a) and the Hauptdolomit (b) 
$0.1 \mathrm{~m}$ in diameter. The fractures are entirely filled up with sparry calcite enriched with reddish bauxitic clayey material.

Above the karstified surface lies an up to $30 \mathrm{~m}$-thick succession of fine-grained terrigenous reddish argillaceous siltstone/sandstone, representing the terrestrialphase horizon. Identically-composed deposits also occur in a few other places of the Karst Dinarides (e.g. Senjsko bilo). According to Sokač et al. (1976) they are usually tuffaceous, forming sporadic lense-shape bodies of variable thickness. At Baške Oštarije, these deposits are usually covered, preventing continuous observation (Fig. 5c). However, in a few places small outcrops occur, which clearly reveal typical characteristics of these beds. Individual beds are $0.1-0.4 \mathrm{~m}$ thick, revealing, in places, horizontal lamination. They typically contain moderately to well-sorted quartz grains, while feldspar and fragments of basic effusive rocks occur only sporadically. These grains are inserted in an altered matrix composed of illite, kaolinite and chlorite. The reddish color of these deposits indicates the presence of hematite. The uppermost part of these deposits is represented by a $0.5-0.7 \mathrm{~m}$-thick, fine-grained breccia/conglomerate interval. It is composed of unsorted subangular to rounded tuffitic pebbles, mostly 2 to $8 \mathrm{~mm}$ in size. These are fairly unconsolidated, even showing a sandy appearance. This breccia interval is followed by a ca. $220 \mathrm{~m}$-thick succession of Norian-Rhaetian dolomite.

\section{The Rogozno Section (Gorski kotar)}

Gorski kotar is located in the northwestern part of Croatia, between Mt. Velebit and Slovenia. In contrast to Mt. Svilaja and Mt. Velebit its central part is mostly covered with soil and vegetation. Thus, thicker conformable packages of fully exposed strata are generally missing. However, along the Zagreb-Rijeka road northwest of Fužine, a 40 m-thick exposure of Lower Triassic deposits overlain by Norian-Rhaetian dolomite occurs (Figs $1 \mathrm{~d}$ and $2 \mathrm{~d}$ ). The Lower Triassic deposits are represented by weathered, yellowish gray, reddish and/or olive gray platy beds $(0.01-0.1 \mathrm{~m})$ composed of thin-bedded, silty and/or sandy dolopelmicrite that irregularly alternates with gray, medium-bedded $(0.1-0.5 \mathrm{~m})$ dolomicrite and/or dolomitic oosparite. Silty and/or sandy dolopelmicrite is composed of dolomitized peloids with variable proportions of mica and quartz grains. These beds commonly reveal horizontal lamination with platy mica grains, oriented parallel to bedding (Fig. 6a). Ooid "ghosts" in dolomitic oosparite range in size from $0.2 \mathrm{~mm}$ to $1.0 \mathrm{~mm}$. The relicts from the ooid inner fabric are rarely preserved in cryptocrystalline replacive dolomite crystals or pseudosparitic mosaics (Fig. $6 \mathrm{~b})$. By means of paleontological analysis of dolomitic oosparite, the Upper Scythian foraminifer Meandrospira pussila (Ho) has been determined (Durdanović 1967). Therefore the facies composition of these Upper Scythian beds differs from those in the Zelovo section. Coarser, recrystallised mollusk fragments in these deposits are only sporadically present. Above a sharp and uneven contact, the topmost Upper Scythian dolomicritic interval is overlain by $4.5 \mathrm{~m}$-thick massive 


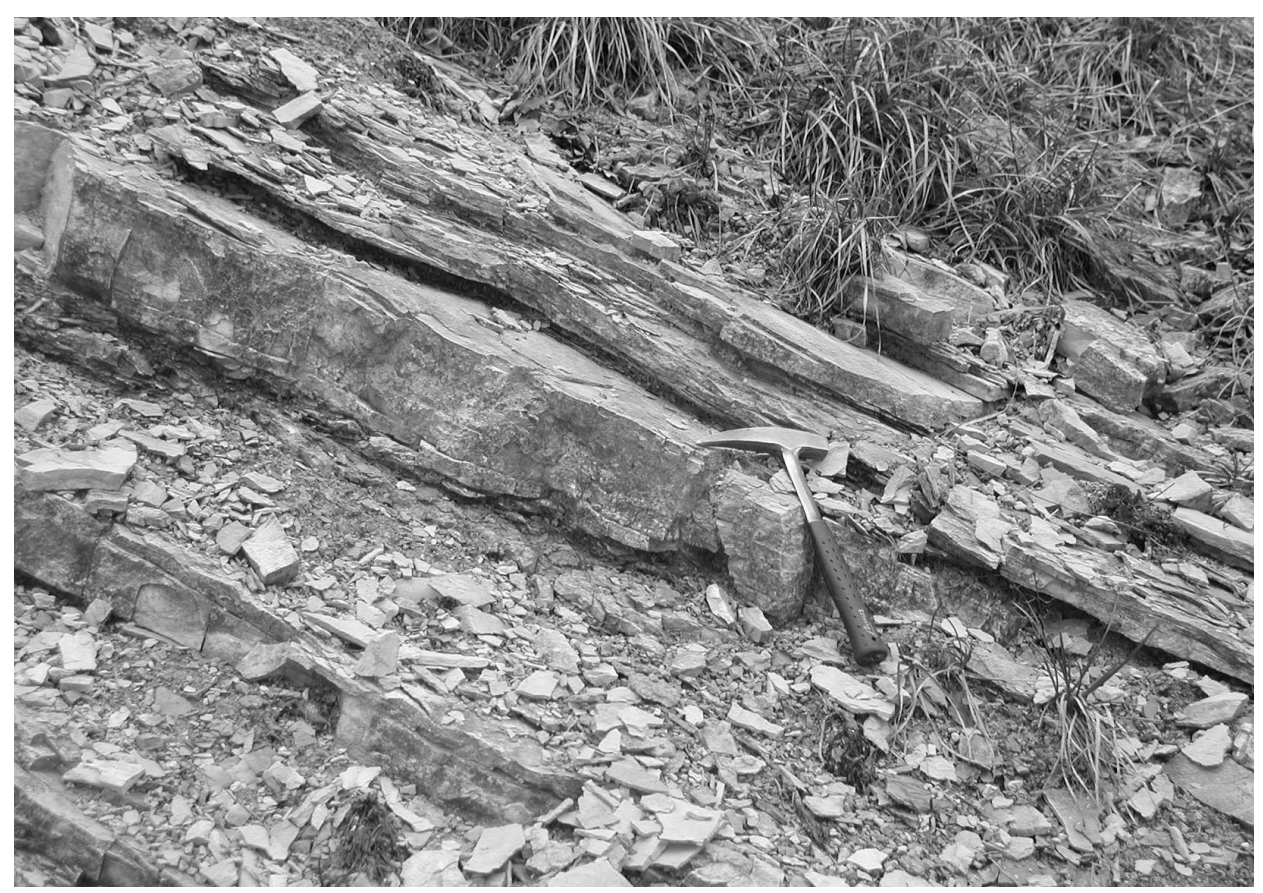

Fig. 6a

Rogozno section. Upper Scythian platy beds of horizontally laminated silty dolopelmicrite

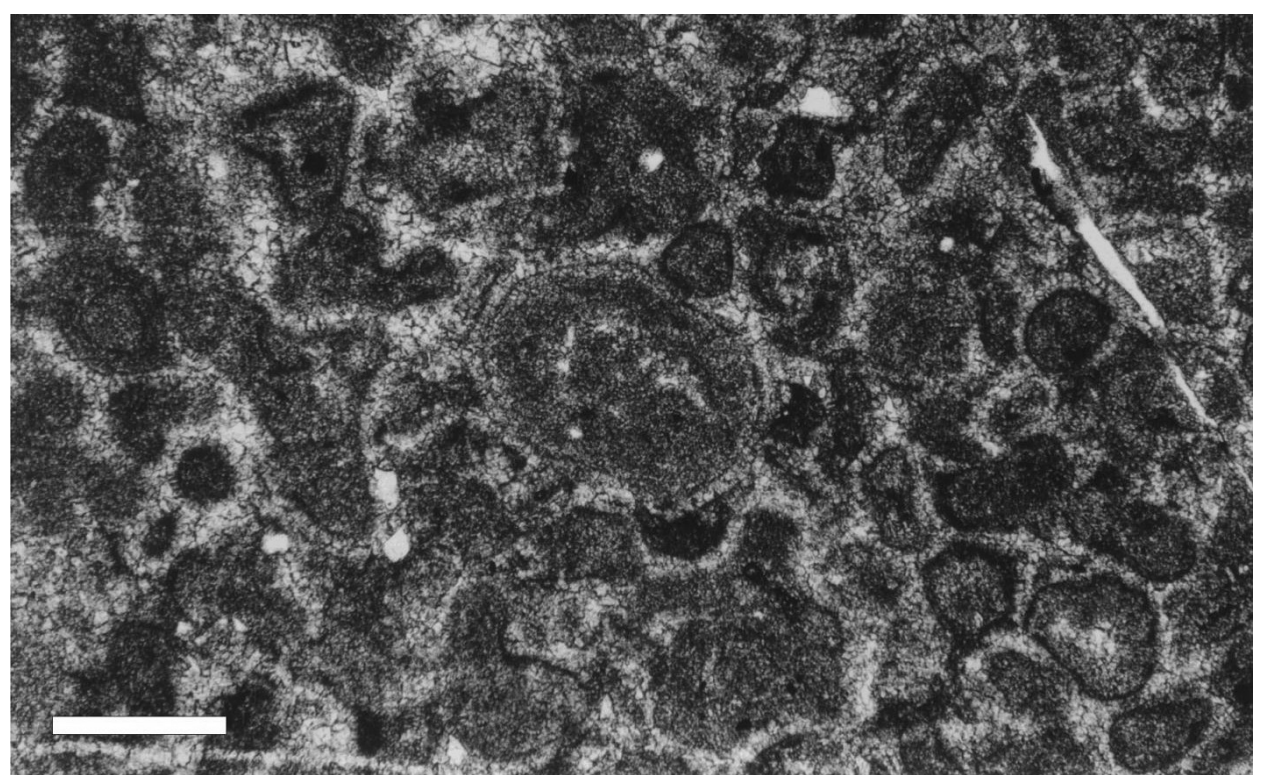

Fig. $6 \mathrm{~b}$

Rogozno section. Ooid "ghosts" in Upper Scythian dolomitic oosparite. Scale bar $0.4 \mathrm{~mm}$ 


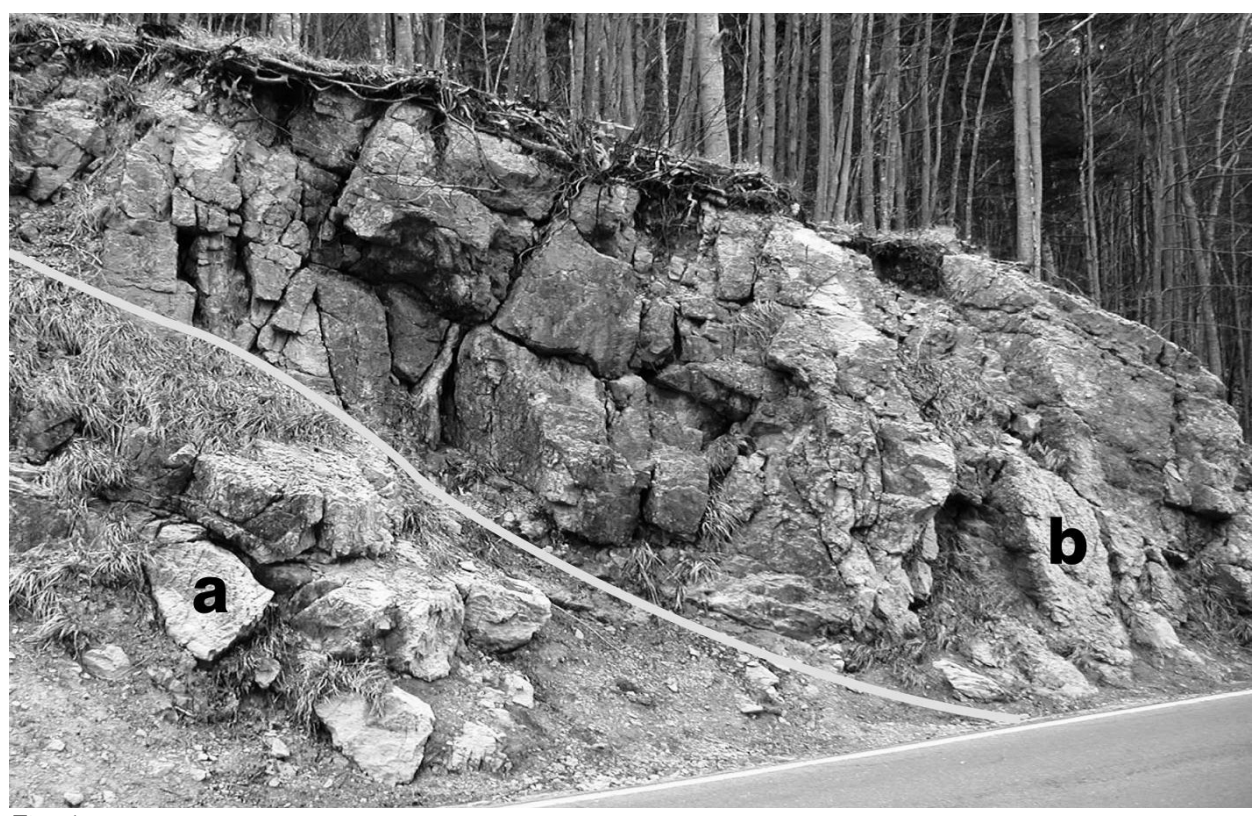

Fig. 6c

Rogozno section. Line marks the contact between Upper Scythian dolomicrite (a) and massive bedded matrix-supported breccia (b)

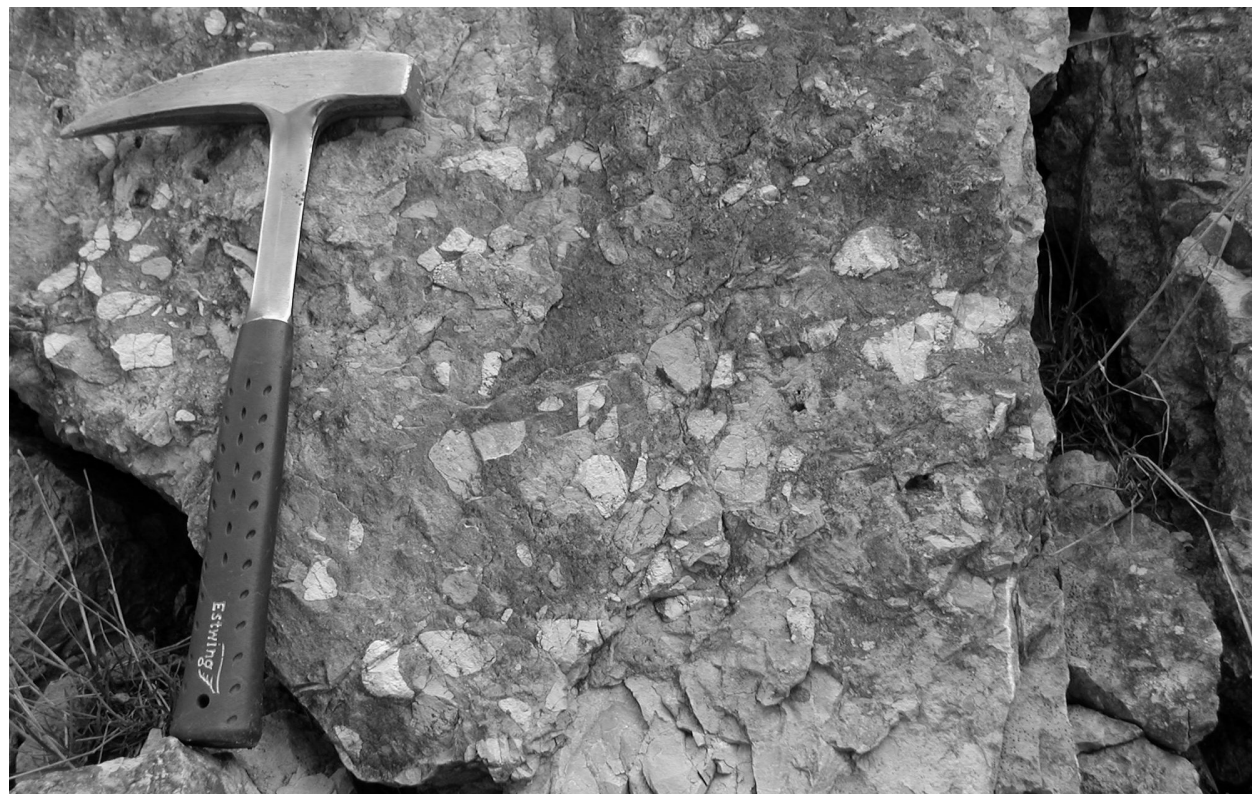

Fig. 6d

Rogozno section. Matrix-supported breccia composed of silty and/or sandy dolopelmicritic and dolomicritic pebbles inserted in dolomitic groundmass 
bedded, matrix-supported breccia (Fig. 6c). It is composed of yellowish gray and reddish silty and/or sandy dolopelmicritic and dolomicritic pebbles, ranging in size from $0.01-0.05 \mathrm{~m}$ (Fig. 6d). The color and lithological characteristics of these pebbles fully correspond to those from the underlying Upper Scythian beds. They are poorly sorted with slight or no apparent grading in a dolomitic groundmass that commonly contains late-diagenetic, eu- to subhedral dolomitic microcrystals. This is then the predominant structural characteristic in the overlying, ca. $250 \mathrm{~m}$-thick succession of Norian-Rhaetian dolomite. Thus, it can be assumed that this matrix-supported breccia belongs to the Early Norian.

According to Durđanović (1967), in the entire dolomite interval of the Rogozno section no fossils can be found. However, at the neighboring Mrzla Vodica locality, the following Norian-Rhaetian foraminiferal species have been determined in the dolomite beds: Triasina hantkeni Majzon, Involutina liassica (Jones), Involutina turgida Kristan, etc. (Durdanović 1967).

\section{Triassic marine environments}

The Lower Triassic deposits from the examined Karst Dinaridic sections reveal complex, storm-induced, processes of variable intensity that took place within the wide and shallow-water Gondwana shelf area (Aljinović 1995). Clear differences among the Lower and Upper Scythian facies, commonly observed throughout the Karst Dinarides, reveal a transgressive trend (Late Scythian sea level rise - e.g. Haq et al. 1988) when the shoreline consequently shifted further toward the Gondwana hinterland. Late Scythian sedimentation therefore took place more distally on an open Gondwana shelf area, predominantly enabling accumulation of carbonate mud that partly and sporadically mixed, in variable proportions, with fine-grained silt- and clay-sized particles, derived from the distant Gondwana land by wind drift currents, sea-bottom currents and/or surface waves.

The Anisian, Ladinian, Norian and Rhaetian sedimentary signatures of the investigated sections are characterized by a lack of terrigenous input. Thus, isolated carbonate platform conditions can be envisaged for the studied depositional area during the Middle-Late Triassic.

However, the Anisian and Ladinian part of Zelovo section clearly indicates that isolated platform sedimentation was partly interrupted by some tuffaceous input derived from a neighboring volcanic area. Along the existing rift faults, the Zelovo area drowned, deepened and became connected with the open Tethys realm populated by a deeper-water biota (ammonites, radiolarians, siliceous sponges, crinoids, etc.). Dissolution of silica-producing organisms and volcanic ash produced movable silica-rich fluids leading to early-diagenetic silicification, which manifested itself in chert intercalations and/or silicified carbonate beds.

The Norian and Rhaetian are represented throughout the Karst Dinarides by a thick dolomite succession with subordinately-preserved features of early- 
diagenetic dolomitization. Numerous lithological varieties of early-diagenetic dolomitic beds imply a peritidal isolated platform environment, where successive shallowing-upward cycles were produced. Nevertheless, late-diagenetic dolomitization destroyed most of the Norian-Rhaetian sedimentary and earlydiagenetic features, so their occurrences in the Karst Dinaridic dolomite successions are fairly sporadic and irregular.

\section{Discussion}

As has been described above, the terrestrial-phase horizon between the second and third megasequences of the Karst Dinarides indicates a break in the shallowmarine carbonate sedimentation regime, when deposition, karstification and/or erosion under subaerial conditions occurred. Eustatic sea level fall was assumed to be responsible for the development of subaerially-exposed sequence boundaries in ancient carbonate successions, which resulted in paleokarsts beneath the sequence boundary (Kerans 1988; Sarg 1988; Fritz et al. 1993: Montafiez and Osleger 1993; Elrick 1996). Estimates of eustasy from sequence stratigraphy indicate that e.g. the Carnian was a time of rapidly changing sea levels. Haq et al. (1988) recognized a rapid Late Ladinian-Early Carnian sea level fall, then an Early Carnian rise followed by a lowstand in the middle part of the Carnian and finally, a Late Carnian highstand. At the Carnian-Norian boundary a rapid sea-level fall was supposed. However, Doglioni et al. (1990) suggested the importance of the tectonic "enhancement" of the Ladinian-Carnian and Late Carnian sequence boundaries, proposing a more complex scenario for Carnian events than models of eustasy would indicate. Applying that Doglioni et al. (1990) suggestion, one can noticed that tectonic activity, i.e. rifting processes and rift-related volcanism, was an important factor in the Paleotethyan shelf area since the Late Permian (Ziegler 1990; Pamić et al. 1998). Thus, during the Middle Triassic, these rifting processes even produced discrete zones of igneous rocks transecting the Paleozoic basement (Channell et al. 1979; Pamić et al. 1998) and isolated, narrow basins in which deep-water chert, pelite and limestone were deposited (Pamić et al. 1998). These Middle Triassic tectonic events led to the formation of a large, isolated platform called the Adria Microplate (Channell et al. 1979). Subsequently a huge portion of that platform was subjected to tectonicallyinduced uplift, superimposed on overall eustatic variations, resulting in a regional emersion phase with strong subaerial erosion throughout the exposed platform area (e.g. Budai and Vörös 1993, 2006; De Zanche et al. 1993; Rüfter and Zühlke 1995; Gianolla et al. 1998; Haas and Budai 1999). Concerning the Karst Dinaridic area, by interplay of ubiquitous processes such as different intensity of subaerial erosion, terrestrial sedimentary input and diachronous Norian transgression, respectively, four types of terrestrial phase horizons were formed during the Middle Triassic and the Carnian. However, in some Karst Dinaridic parts (e.g. in western Slovenia, in the vicinity of Karlovac in central Croatia, or in 
western and central Bosnia and Herzegovina, or northern and southern Montenegro - Vlahović et al. 2005), there is no evidence for such a regionally significant shallow-marine sedimentation break indicating a different geodynamic scenario, which is beyond the scope of this study.

The most intensive erosion took place in the Gorski kotar area, producing in the Rogozno section a clear disconformity and related stratigraphic gap between the Upper Scythian and Lower Norian (Babić 1968). As matrix-supported breccia and/or conglomerate are common characteristics of mass flow deposits (e.g. Ager 1993), it can be assumed that during the Early Norian transgression, severe storm events (hurricanes or severe tropical storms) occurred, carrying fine-grained carbonate mud and ripped up pieces of the shallow sea floor bottom composed of Upper Scythian beds. The catastrophic flood was very erosive, removing the karstic residual clasts and weathering products (paleosol), forming a thick, massive bed of matrix-supported breccia above the sharp and uneven surface of the underlying Upper Scythian beds.

Anisian-Early Ladinian volcanic activity, clearly noticed within the Zelovo section, produced a significant amount of volcanic ash that spread and cover some nearby areas. Since at the Baške Oštarije section, paleokarstification affected only a relatively thin interval that is typified only by numerous dissolution-enlarged fractures, it can be supposed that during subaerial exposure, covering by fallen volcanic ash blocked any further pervasive erosion of underlying Upper Anisian carbonates. Unlike the Rogozno section, a thin interval of fine-grained transgressive tuffaceous breccia/conglomerate points to much calmer conditions during the Early Norian transgression, when underlying tuffaceous beds were only lightly reworked.

At the Zelovo section the terrestrial phase can be recognized in terms of paleokarst-related solution-collapse breccia, as has been described f.i. by Ryu et al. (1997). Thus, one can assume that overall regression during the Late Ladinian caused extensive dissolution of Upper Ladinian limestone and resulted in extensive karstification, with solution-enlarged vugs and small caverns beneath the platform surface, producing clast- to matrix-supported chaotic breccia that rested sharply on intact Upper Ladinian beds. Active carbonate dissolution ceased due to subsequent transgression when sediment loading caused local collapse and fragmentation of the karstified surface. Continued burial led to further fracturing and in situ brecciation, resulting in a mosaic and fracture breccia horizon. The small thickness of the dolomite interval (only $60 \mathrm{~m}$ ) that overlies the breccia horizon suggests that the transgression began here later than in the other platform areas. This is clearly indicated by much thicker Hauptdolomit successions (regularly exceeding $200 \mathrm{~m}$ ) in most other Karst Dinaridic areas. It can thus be assumed that the transgression in the Zelovo area did not take place before the Late Norian.

A different scenario is envisaged for the terrestrial-phase horizon at the Vrace section. A wide local karstic depression developed here, surrounded by Upper 
Ladinian rocks. The depression was filled with pelitic and colloidal clayey material derived from a Ladinian volcanic-sedimentary complex (e.g. today's Donje Pazarište and/or Vratnik area - Lugović 1983; Marci et al. 1990), affected by chemical weathering under subaerial conditions. Chemical weathering of the volcanic rocks led to decomposition and/or dissolution that resulted in formation of kaolinite, chlorite, illite, etc. By means of fresh water flows and/or by wind, these residuals were transported and then accumulated in the paleorelief depressions, a situation most alike to shallow-water lacustrine environments. The warm and humid Carnian climate was very favorable for laterization processes, so the accumulated material was diagenetically altered, forming thick claystone/bauxite deposits. The reddish conglomerate was formed during storm events, when both erosion of claystone/bauxitic material in the shallow-water pools and reworking of fragments of the karstified Ladinian rocks that surrounded the paleodepression took place. The carbonate conglomerate beds that occur at the top of the claystone/bauxite were formed during the Early Norian marine transgression, when the abrasion of karstified Ladinian rocks that surrounded the paleodepression became the predominant process. The ferruginous matrix within the lower part of the conglomerate interval came from the final resedimenation of the underlying claystone/bauxitic material, while its absence in the upper part of the conglomerate interval indicates advanced transgression and the beginning of the Norian shallow-marine platform conditions.

\section{Conclusion}

The Lower/Middle to upper part of the Upper Triassic interval in Karst Dinaridic sequence is characterized by a regional unconformity related to an emersion that was a consequence of Middle Triassic Adria Microplate uplift. Strong erosion prior to the Norian transgression formed an uneven denudation surface built up by the subaerially exposed remnants of the Lower to Middle Triassic strata, during which four variable terrestrial phase horizons were formed. Consequently the stratigraphic gap created in this fashion and placed between the second and third Karst Dinaridic megasequences is determined by the time span of the denudation period.

A Late Scythian to Early Norian stratigraphic gap occurs between the two megasequences in the Rogozno area, implying very intensive erosion processes during the subaerial exposure. Similar conditions can be envisaged for the Baške Oštarije area; however, eolian sedimentation of volcanic ash stopped further pervasive erosion, and thus almost the entire Anisian sequence was preserved. At this location, therefore, the terrestrial phase apparently lasted from the Late Anisian to the Early Norian. In the Zelovo area the processes of paleokarstification were very pervasive, producing a thick breccia/conglomerate horizon during the Late Norian transgression. Thus the terrestrial phase lasted 
from the Late Ladinian to the late Norian. In the Vrace area the emergent terrain was tectonically shaped as a depression that become a lacustrine environment, filling up with pelitic and colloidal clayey material derived by eolian and/or fresh water transport, which was subsequently altered to claystone/bauxite. Here, the terrestrial phase lasted from the Late Ladinian to the Early Norian.

Due to an overall, diachronous Norian transgression, all these emergent Karst Dinaridic areas were flooded and a shallow-water platform regime was restored over the entire Adria Microplate realm, signifying a new stage in its evolution.

\section{Acknowledgements}

This paper is a contribution to the Project No. 119-1191152-1171 supported by the Ministry of Science, Education and Sports of the Republic of Croatia. I thank Dr. J. Haas and Dr. T. Budai for reviewing the manuscript and providing justified criticism and constructive and valuable suggestions that essentially improved the paper.

\section{References}

Ager, D.V. 1993: The new catastrophism: the importance of the rare event in geological history. Cambridge University Press, Cambridge, New York, 251 p.

Aljinović, D. 1995: Storm influenced shelf sedimentation - an example from the Lower Triassic (Scythian) siliciclastic and carbonate succession near Knin (southern Croatia and western Bosnia and Herzegovina). - Geol. Croatica, 48/1, pp. 17-32, Zagreb.

Aljinović, D. 1997: Facies of clastic sediments in Late Palaeozoic and Early Triassic of Gorski Kotar. Unpubl. Ph.D. Thesis, University of Zagreb, 163 p.

Babić, Lj. 1968: Sur le Trias dans le Gorski Kotar et les régions voisines. - Geol. vjesnik, 21, pp. 11-18, Zagreb.

Budai, T, A. Vörös 1993: The Middle Triassic events of the Transdanubian Central Range in the frame of the Alpine evolution. - Acta Geologica Hungarica, 35/3, pp. 237-259.

Budai, T, A Vörös 2006: Middle Triassic platform and basin evolution of the Southern Bakony Mountains (Transdanubian Range, Hungary). - Revista Italiana Paleontologica, 112/3, pp. 359-371.

Channell, J.E.T, B. D'Argenio, F. Horváth 1979: Adria, the African promontory, in Mesozoic Mediterranean palaeogeography. - Earth-Science Review, 15/3, pp. 213-292.

De Zanche, V., P. Gianolla, P. Mietto, Ch. Siorpaes, P. Vail 1993: Triassic sequence stratigraphy in the Dolomites (Italy). - Memorie Scienze Geologiche, 45, pp. 1-27, Padova.

Doglioni, C., A. Bosellini, P.R. Vail 1990: Stratial patterns; a proposal of classification and examples from the Dolomites. - Basin Research, 2, pp. 83-95, Oxford.

Durdanović, Z. 1967: The Lower Trias of the Gorski Kotar region. - Geol. vjesnik, 20, pp. 107-110.

Elrick, M. 1996: Sequence stratigraphy and platform evolution of Lower-Middle Devonian carbonates, eastern Great Basin. - Geological Society of America Bulletin, 108, pp. 392-416.

Fio, K., J. Spangenberg, J. Sremac, I. Vlahović, I. Velić, E. Mrinjek 2006: Causes of Permian/Triassic mass extinction at the Velebit Mt., Croatia: geochemical and isotopical insights. - Book of Abstracts, 2. Slovenski geološki kongres, p. 80, Idrija.

Fio, K, J. Spangenberg, J. Sremac, I. Vlahović, I. Velić, E. Mrinjek 2007: Molecular and Isotopic Records of the Permian-Triassic Transition at the Velebit Mt., Croatia. - In: Tâmas, T., B.P. Onac, 
I.I. Bucur (Eds): Proceedings of the European Society for Isotope Research, ESIR IX, 27-28, ClujNapoca.

Fritz, R.D., J.L. Wilson, D.A. Yurewicz 1993: Paleokarst related hydrocarbon reservoirs. - Society of Economic Paleontologists and Mineralogists Core Workshop, 18, 275 p. Tulsa.

Grimani, I., M. Šušnjar, J. Bukovac, A. Milan, J. Nikler, J. Crnolatac, I. Šikić, I. Blašković 1973: Basic Geological Map of SFRJ, 1:100000, Geology of Crikvenica sheet, 5-47. - Inst. za geol. istraž., Zagreb.

Gianolla, P., V. De Zanche, P. Mietto. 1998: Triassic sequence stratigraphy in the Southern Alps (Northern Italy): definition of sequence and basin evolution. - In: Graciansky, P.C., J. Hardenbol, T. Jacquin, P.R. Vail (Eds): Mesozoic-Cenozoic Sequence Stratigraphy of European Basins. - SEPM Spec. Publ., 60, pp. 723-751.

Haq, B.U., J. Hardenbol, P.R. Vail 1988: Mesozoic and Cenozoic chronostratigraphy and cycles of sealevel change. - In: Wilgus, C.K., B.S. Hastings, C.A. Ross, H. Posamentier, J. Van Wagoner, C.G.S.C. Kendall (Eds): Sea-Level Changes - An Integrated Approach, SEPM Spec. Publ., 42, pp. 71-108, Tulsa.

Haas, J., T. Budai 1999: Triassic sequence stratigraphy of the Transdanubian Range, Hungary. Geologica Carpathica, 50/6, pp. 459-475.

Husinec, A., V. Jelaska 2006: Relative sea-level changes recorded on an isolated carbonate platform: Tithonian to Cenomanian succession, southern Croatia. - Journal of Sedimentary Research, 76, pp. 1120-1136, Boulder.

Ivanović, A., K. Sakac, S. Marković, B. Sokač, M. Šušnjar, L. Nikler, A. Šušnjara 1973: Basic Geological Map of Yugoslavia 1:100 000, Obrovac sheet. - Institut za geološka istraživanja, Zagreb.

Ivanović, A., K. Sakać, B. Sokač, I. Vrsalovic-Carević, J. Zupanić 1976: Basic Geological Map of SFRJ, 1:100000, Geology of Obrovac sheet, 5-55. - Institut za geološka istraživanja, Zagreb.

Jelaska, V., D. Benček, D. Matičec, M. Belak, I. Gušić 2000: Geological history and structural evolution of the Outer Dinarides. - In: Vlahović, I, R. Biondić (Eds): Excursion Guide-Book, Second Croatian Geological Congress, pp. 1-12, Zagreb.

Jelaska, V., T. Jurkovšek-Kolar, B. Jurkovšek, I. Gušić 2003: Triassic beds in the basement of the Adriatic-Dinaric carbonate platform of Mt. Svilaja (Croatia). - Geologija, 46/2, pp. 225-230.

Jurković, I., J. Pamić 2001: Geodynamics and metallogeny of Variscan complexes of the Dinarides and South Tisia as related to plate tectonics. - Nafta, 52/9, pp. 267-284.

Kerans, C. 1988: Karst-controlled reservoir heterogenecity in Ellenburger Group carbonates of west Texas. - American Association of Petroleum Geologists Bulletin, 72, pp. 1160-1183.

Kiessling, W., E. Flügel, J. Golonka 2003: Patterns of Phanerozoic carbonate platform sedimentation. - Lethaia 36, pp. 195-226.

Kochansky-Devidé, V. 1965: Carboniferous and Permian fusulinids of the Velebit Mt. and Lika region. Middle and Upper Permian. - Acta Geol., 5, pp. 101-137, Zagreb.

Krainer, K. 1993: Late- and Post-Variscan Sediments of the Eastern and Southern Alps. - In: Von Raumer, J.F., F. Neubauer (Eds): Premesozoic Geology in the Alps. Springer-Verlag, pp. 537-564, Berlin, Heidelberg.

Lugović, B. 1983: Magmatic rocks of Senjska Draga (Vratnik) near Senj (Croatia, Yugoslavia). - Geol. vjesnik, 36, pp. 157-181.

Marci, V., G. Pleteš, Z. Bosak, D. Šatara 1990: First appearance of accretionary lapili in Triassic rocks near Donje Pazarište. - Geol. vjesnik, 43, pp. 113-120.

Montafiez, I.P., D.A. Osleger 1993: Parasequence stacking patterns, third-order accommodation events, and sequence stratigraphy of Middle to Upper Cambrian platform carbonates. Bonanza King Formation, Southern Great Basin. - In: Loucks, R.G., J.F. Sarg (Eds): Carbonate Sequence Stratigraphy. American Association of Petroleum Geologists Memoir, 57, pp. 302-326, Tulsa.

Pamić J., I. Gušić, V. Jelaska 1998: Geodynamic evolution of the Central Dinarides. - Tectonophysics, 297, pp. 251-268. 
Papeš, J., R. Marinković, V. Raić, N. Magaš, V. Sikirica 1982: Basic Geological Map of Yugoslavia 1:100 000, Sinj sheet. - Geoinženjering-Institut za geologiju, Sarajevo, Institut za geološka istraživanja, Zagreb.

Ramovš, A., A. Hinterlechner-Ravnik, M. Kalenić, S. Karamata, Sv. Kochansky-Devidé, M. Mirković, P. Petkovski, J. Sremac, B. Krstić, E. Kulenović, V. Temkova. 1990: Stratigraphic correlation forms of the Yugoslav Paleozoic. - Rend. Soc. Geol. Ital., 12, pp. 359-383, Roma.

Rüffer, Th., R. Zühlke 1995: Sequence stratigraphy and sea-level changes in the Early to Middle Triassic of the Alps: a global comparison. - In: Haq, B.U. (Ed.): Sequence stratigraphy and depositional response to eustatic, tectonic and climatic forcing. - Kluwer Academic Publishers, Dordrecht, Boston, London, pp. 161-207.

Ryu, I.C., S.J. Doh, S.G. Choi 1997: Carbonate breccias in the Lower-Middle Ordovician Maggol Limestone (Taebacksan Basin, South Korea): Implications for Regional Tectonism. - Facies, 46, pp. 35-56, Erlangen.

Sarg, J.F 1988: Carbonate sequence stratigraphy. - In: Wilgus, C.K., H. Posamentier, C.A. Ross, C.G.St.C. Kendall (Eds): Sea-level changes: an integrated approach. - Society of Economic Paleontologists and Mineralogists Special Publication, 42, pp. 155-181, Tulsa.

Savić, D., S. Dozet 1984: Basic Geological Map of Yugoslavia 1:100 000, Delnice sheet. - Institut za geološka istraživanja, Zagreb.

Sokač, B, L. Nikler, I. Velić, P. Mamuzić 1974: Basic Geological Map of Yugoslavia 1:100 000, Gospić sheet. - Institut za geološka istraživanja, Zagreb.

Sokač, B., B. Šcavnicar, I. Velić 1976: Basic Geological Map of SFRJ, 1:100000, Geology of Gospić sheet, 5-64. - Institut za geološka istraživanja, Zagreb.

Sremac, J. 2005: Equatorial Shelf of the Palaeozoic Supercontinent - Cradle of the Adriatic Carbonate Platform. - Geol. Croatica, 58/1, pp. 1-19, Zagreb.

Šinkovec, B. 1970: Geology of the Triassic bauxites of Lika, Yugoslavia. - Acta Geol., 7, pp. 5-70, Zagreb.

Tišljar, J., I. Vlahović, J. Sremac, I. Velić, V. Veseli, D. Stanković 1991: Excursion A - Velebit Mt., Permian-Jurassic. Int. simp. on the Adriatic carbonate platform. - In: Vlahović, I., I. Velić (Eds): Excursion guide book, pp. 4-34, Zagreb.

Velić, I., I. Vlahović, D. Matičec 2002: Depositional sequences and palaeogeography of the Adriatic carbonate platform. - Mem. Soc. Geol. It., 57, pp. 141-151.

Vlahović, I., J. Tišljar, I. Velić, D. Matičec 2005: Evolution of the Adriatic carbonate platform: palaeogeography, main events and depositional dynamics. - Palaeogeography, Palaeoclimatology, Palaeoecology, 220/3-4, pp. 333-360.

Ziegler, P.A. 1990: Geological Atlas of Western and Central Europe. - Shell Internationale Petroleum Maatschappij B.V, pp. 1-239, Den Haag. 